\title{
Synthesis of Rod/Spherical-Gold Nanoparticles (AuNPs) to Overcome Multidrug-Resistant Bacteremia
}

\author{
Alia A. Shoeib ${ }^{1,3 *}$, Awatif A. Hindi ${ }^{2}$ and Mashail F.S. Alsayed ${ }^{3}$
}

\begin{abstract}
Multidrug-resistant bacteremia $15 \mathrm{G}^{-}$ve and $1 \mathrm{G}^{+}$ve isolates were collected from inpatients and outpatients departments at Security Forces Hospital in Riyadh, Saudi Arabia. In studying the multidrug-resistance to antibiotics,

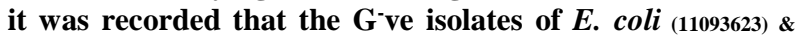
(11161644) were resistance to 19 out of 20 tested antibiotics except antibiotic $(\mathrm{CN})$, while the $\mathrm{G}^{+}$ve isolate of MRSA was resistance to 9 out of 18 antibiotics, and it was sensitive to antibiotic $(\mathrm{OX}$ and $\mathrm{CZ})$.
\end{abstract}

The Gold Nanoparticles (AuNPs) was examined to discourage the growth of the multidrug-resistance isolates. Rod-AuNPs were the best to discourage the growth of tested bacteria, followed by the Spherical-AuNPs. Swabs were taken from inhibition zone resulting from the inhibitory effect of AuNPs, towards the tested bacteria and re-inoculated on the Nutrient Agar medium, to determine either the bacteriostatic/bactericidal effect for different NPs. The study proved that Rod-AuNPs gave bacteriostatic effect on Pseudomonas aeruginosa (11093627) \& (11132667), Enterobacter cloacae (11159053) and Citrobacter freundii(11176991)\&(11182565), and gave a bactericidal effect to the rest of the tested isolates. The Spherical-AuNPs gave a bacteriostatic impact of all tested isolates.

Electromicroscopic studies disclosed the effect of AuNPs, either rods or spherical-shaped, on the external shape of some of the pathogenic tested bacteria e.g. $E$. coli, Klebsiella pneumoniae and $P$. aeruginosa of $\mathbf{G}^{-}$ve bacteria,

MRSA of $\mathrm{G}^{+}$ve bacteria. From results obtained, it can be concluded that the nanostructures and morphologies of AuNPs may offer new possibilities for promising therapeutic applications of multidrug-resistance bacteremia.

Keyword: Rod-Gold Nanoparticles, Spherical-AuNPs, Multidrug-Resistant, Bacteremia, bloodstream, SEM, E. coli, Pseudomonas, Klebsiella, Acinetobacter, Stenotrophomonas, Salmonella, Citrobacter.

\section{INTRODUCTION}

The blood is usually a sterile environment, so detection of bacteria in the blood is always abnormal. It is considered one of the richest environments with nutrients, which leads to the possibility of bacterial infection with serious and even incurable blood diseases, and sometimes transmitted in the current era through blood transfusions (Volk, et al., 1986). The presence of bacterial cells in the bloodstream called bacteremia and can occur as a result of daily work like cleaning teeth (Irving, 2004). Lots of bacteria can cause bacteremia in blood as a secondary infection or as a result of infecting many organs in the body. They are opportunistic pathogens of humans, and they are commonly spread in hospitals (Mylonakis, et al., 2006).

Commercial antimicrobial drugs have been commonly employed as treatment for infectious diseases for over the past nearly seventy-five years. Therefore, the indiscriminate use of these antibiotics has developed multiple resistances and side effects. So, more natural substances, which possess antimicrobial activity, were desired, instead of antibiotics (Mothana and Lindequist, 2005, Limsuwan, et al., 2009 and Podolsky, 2018).

Bloodstream infections called bacteremia, are an important cause of morbidity and mortality in the haematology population, and may contribute to delayed administration of chemotherapy, increased length of hospitalisation, and increased healthcare expenditure (Worth and Salvin, 2008).

Bacteremia due to Escherichia coli is usually associated with urinary tract infections or gastrointestinal tract infections, cholecystitis and cholangitis result from obstruction of the biliary system from biliary stone or sludge leading to stagnation and bacterial growth, and partial obstruction is associated with a higher rate of infection bacteremia, E. coli bacteremia precedes pneumonia and meningitis in newborns (Donnenberg, et al., 1993).

The ability of Klebsiella pneumonia to spread rapidly often leads to occur bacteremia. Most Klebsiella infections are acquired during hospital stays especially multidrug-resistant strains in new born wards (Podschun, et al., 1998). Whereas, P. aeruginosa accounts for about $25 \%$ of all hospital acquired $\mathrm{G}^{-} \mathrm{ve}$ bacteremias (Ryan and Ray, 2004). Staphylococcus aureus is a $\mathrm{G}^{+} \mathrm{ve}$ bacteremia that is a major cause of

DOI: 10.21608/asejaiqjsae.2021.193090

${ }^{1}$ Department of Plant Pathology, Faculty of Agriculture, Alexandria University, Alexandria, Egypt.

${ }^{2}$ Department of Physics and Astronomy, College of Science, King Saud University, Saudi Arabia.

${ }^{3}$ Department of Botany and Microbiology, College of Science, King Saud University, Saudi Arabia.

*Corresponding author: A.A. Shoeib, Email: aliashoeib@alexu.edu.eg,

ORCID id: 0000-0002-7075-2780.

Received August 06, 2021, Accepted, September 02, 2021. 
hospital acquired (nosocomial) infection either by direct or indirect contact (Aramburu, et al., 2006).

Many researches have recorded the multidrugresistant bacteremia and different genera/species isolates; e.g. E. coli (Javaloyas, et al., 2003; Bin, et al., 2006), Streptococcus pneumoniae (Kaplan and Mason, 1998 and $\mathrm{Yu}$, et al., 2003), Salmonella bacteremia (Grisaru-Soen, et al., 2004), methicillin-resistant S. aureus (MRSA) bacteremia (Fowler, et al., 2006), complicated bacteremia $K$. pneumoniae with $E$. coli (Sun, et al., 2006).

The new approach for the functional Gold Nanoparticles (AuNPs) can be used as photothermal agents for the selective killing of pathogenic bacteria. AuNPs with polygonal shapes, capable of absorbing near infrared light, were generated through a photochemical reaction (Hung, et al., 2007). The antimicrobial activity of AuNPs was evaluated with antibiotic susceptible and resistant microorganisms. In addition, the structure and properties of gold NPs make them useful for a wide array of biological application. Toxicity, however, has been observed at high concentrations using these systems (Goodman, et al., 2004).

Thus the aim of this study was to determine bacterial genera that caused bloodstream infection which exhibit resistance to antibiotics that are used in treatment for certain patients at Security Forces Hospital in Riyadh, Saudi Arabia. And upon it is to detect the multidrugresistance pattern among the isolates of bacteremia. Then study the efficacy of AuNPs against blood pathogenic isolates simultaneously from community and hospitalized patients. Electromicroscopic study was also conducted in order to study the effects of NPs on the external shape of the pathogenic tested bacteria: E. coli, $K$. pneumoniae and $P$. aeruginosa of $\mathrm{G}^{-} \mathrm{ve}$ bacteria and

S. aureus (MRSA) of $\mathrm{G}^{+}$ve bacteria.

\section{MATERIAL AND METHODS}

\section{Samples Collections}

Samples, data, as well as, isolates of bacteria were collected from hospitalization files from May to July 2009. Bacterial test confirmation; bacterial identification and sensitivity testing were carried out by the clinical bacteriology laboratory at Security Forces Hospital in Riyadh (This hospital for patients Saudis only) (Alsayed, et al., 2015).

\section{Antibiotic Sensitivity Pattern of Bacteremia Isolates}

All tested bacterial isolates either $\mathrm{G}^{+} \mathrm{ve}$ or $\mathrm{G}^{-} \mathrm{ve}$ were tested for their sensitivity to antibiotics by means of the disc diffusion method by the method of Kaçmaz and Aksoy (2005) employing multiple antibiotic discs, as the following:1) Dipping the cotton swab in bacterial suspension in concentration 0.5 McFarland Standard (Azu et al., 2007). 2) Streaking the inoculations on plates of Iso- sensitest agar using rotary platter. 3) Leaving the plates around 15 minutes to insure the dryness of the media after inoculating. 4) Putting the discs of different antibiotics on the surface of inoculating agar. 5) Incubating the plates at $37^{\circ} \mathrm{C}$ for 24 hours. 6) Monitoring sensitivity by visualizing the zone of inhibition around the disc. 7) Estimating the effect of antibiotics by measuring the zone of inhibition.

This study included representative multidrugresistant isolates that were obtained from positive blood cultures of inpatients and outpatients of all age groups. Isolates were considered multidrug-resistant if they displayed resistance to 3 or more different antibiotics.

All isolates and standard control strains were tested for antibiotic sensitivity prior to use. Antibiotic tests were made in Iso- Sensitive Agar. Standard control strains were used throughout the study.

As Security Forces Hospital Bacteriology Lab Protocol, the antibiotics were tested on each disc $(\mu \mathrm{g})$ as follows:1) Ampicillin ${ }_{(\mathrm{AmP}) 30}$, Gentamicin ${ }_{(\mathrm{CN}) 10}$ and Cefotaxime $_{(\mathrm{FOX}) 30}$, for G-ve bacteria ring. 2) Amikacin $_{(\mathrm{AN}) 30}$, Piperacillin (PIP)100, Tobramycin $($ (TOB)10, Norfloxacin $_{(\mathrm{NOR}) 10}$ and Levofloxacin $(\mathrm{LVX}) 5$, for Pseudomonas bacteria ring. 3) Ceftriaxone $(\mathrm{CRO}) 30$, Cefuroxme $_{(\mathrm{CXM}) 30}$, for Extra $\mathrm{G}^{-} v \mathrm{ve}$ bacteria ring1. 4) Aztreonam $_{(\mathrm{ATM}) 30}$, Imipenem $(\mathrm{IPM}) 10$, Ciprofloxacin $(\mathrm{CIP}) 5$ and Ceftazidime ${ }_{(\mathrm{CAZ}) 30}$, for Extra $\mathrm{G}^{-}$ve bacteria ring 2. 5) Ampicillin $_{(\mathrm{AMP}) 10}$, Penicillin $(\mathrm{P}) 1$, for $\mathrm{G}^{+} \mathrm{ve}$ bacteria ring. 6) Cefotaxime $(\mathrm{FOX}) 30, \quad$ Ciprofloxacin ${ }_{(\mathrm{CIP}) 5}$, Vancomycin $_{(\mathrm{VA}) 30}$ and Cefuroxme $_{(\mathrm{CXM}) 30}$, for Staphylococcus bacteria Extra ring. 7) Ceftriaxone $_{(\mathrm{CRO}) 30}$, Gentamycin ${ }_{(\mathrm{CN}) 10}$, Oxacillin ${ }_{(\mathrm{OX}) 1}$, for Streptococcus bacteria Extra ring. 8) other antibiotics used: Amoxacillin/Cavulinicacid (Augmentin) (AMC)30, Ofloxacin $_{(\mathrm{OFX}) 30}, \quad$ Sulphamethoxazole/Trimethoprim (SXT)25, Cefazolin $(C Z) 30$, Nalidixic $\operatorname{Acid}_{(\mathrm{NA}) 30}$, Nitrofurantoin $_{(\mathrm{FM}) 300}$ and Cephalotin $(\mathrm{CF}) 30$.

Positive cultures were submitted for antibiotic sensitivity test using the disk diffusion method and results were expressed as sensitive or resistant according to the National Committee for Clinical Laboratory Standards (NCCLS) (1999). Antibacterial activity of AuNPs was determined by using the agar well diffusion method by (Jigna, et al., 2006) on Mueller-Hinton (M.H.) agar medium.

Sterile cork borer was placed alternatively on the Petri plates, two wells of $11 \mathrm{~mm}$ diameter were made into previously seeded M.H. agar plates, to which 500 $\mu \mathrm{l}$ of solution of AuNPs was introduced in each hole of the medium and was placed inside the refrigerator for about two hours for proper diffusion. Each extract and control was incubated at $37^{\circ} \mathrm{C}$ for $24 \mathrm{~h}$. The same 
quantity of sterile distilled water was taken as control. The sensitive bacteria grew everywhere except in areas around the holes in the medium. Then, the resulting inhibition zones obtained were measured in millimeters. Studies were performed in triplicate.

\section{Preparation of Spherical-AuNPs}

The method pioneered by Turkevich, et al. (1951) and Frens (1972 and 1973) and refined by Kimling, et al., (2006) is the simplest one available. Generally, it is used to produce modestly mono disperse sphericalAuNPs suspended in water of around $10-20 \mathrm{~nm}$ in diameter. $5.0 \times 10^{-6} \mathrm{~mol}$ of $\mathrm{HAuCl}_{4}$ (Sigma-Aldrich,ST. Louis, MI) dissolve it in $19 \mathrm{ml}$ of deionized water (the result should be a faintly yellowish solution), heat it until it boils, continue the heating and, while stirring vigorously, add $1 \mathrm{ml}$ of $0.5 \%$ sodium citrate (SigmaAldrich, ST. Louis, MI) solution; keep stirring for the next 30 minutes (the color is wine-red).

\section{Preparation of Rod-Gold Nanoparticles (Rod- AuNPs)}

To prepare seed solution, the Rod-AuNPs were synthesized by some modifications of a method based on the Au seed-mediated growth. $25 \mathrm{ml}$ of aqueous 0.01 $\mathrm{M} \mathrm{HAuCl} \mathrm{H}_{4}-3 \mathrm{H}_{2} \mathrm{O}$ was mixed with $7.5 \mathrm{ml}$ of $0.1 \mathrm{M}$ CTAB (Sigma-Aldrich, ST. Louis, MI) solution by gentle inversion.

The solution was followed by the addition of $0.6 \mathrm{ml}$ of $0.01 \mathrm{M}$ ice-cold $\mathrm{NaBH}_{4}$ solution with rapid inversion mixing for 2 min to yield small AuNPs in a pale brownish yellow solution. This seed solution was stored at $25 \mathrm{C}^{\circ}$ for 2-3 $\mathrm{h}$ after preparation and used in a day. All glassware was thoroughly cleaned with acetone and filtered ultrapure deionized water.

The growth solution of the Rod-AuNPs was prepared using appropriate quantities of each chemical stock solution and mixed together in the appropriate order. All stock solutions were made just prior to use and all Rod-AuNPs batches were completed from start to finish within a period of $7 \mathrm{~h} .9 .7 \mathrm{ml}$ of $0.1 \mathrm{M} \mathrm{CTAB}$ solution was mixed with $0.75 \mathrm{ml}$ of $0.01 \mathrm{M} \mathrm{HAuCl}_{4}$. To this solution, $0.05 \mathrm{ml}$ of $0.02 \mathrm{M} \mathrm{AgNO}_{3}$ (SigmaAldrich, ST. Louis, MI) solution was added, followed by gentle mixing by inversion. At this stage, the color of the solution seemed to be bright brown-yellow. To prevent long reaction times in Rod-AuNPs synthesis (Sau and Murphy, 2004), a reducing agent of $0.054 \mathrm{ml}$ of 0.18 M AA (L-ascorbic acid, Sigma- Aldrich, ST. Louis, MI) was then added before the addition of 0.12 $\mathrm{ml}$ of the seed solution as final step. Ascorbic acid changed the color of the growth solution from yellow to colorless. The final concentration of Rod-AuNPs in the solution was $4 \mathrm{mg} / \mathrm{ml}$.

\section{Antibacterial Activity of AuNPs}

To know the impact of AuNPs which may be useful in developing compound(s) to combat deadly diseases, the following experiments were performed:

\section{Evaluation of the Bacteriostatic/Bactericidal Aspect after Exposure to AuNPs}

The clear zone of inhibition was swabbed using a sterile cotton swab, the same swab was used to spread over the new plates containing Nutrient Agar (NA) medium in order to figure out bacteriostatic/bactericidal aspect of AuNPs (Shoeib and Alkufeidy, 2014).

\section{Scanning Electron Microscope (SEM) Studies}

Isolates E. coli(11161644), Klebsiella pneumoniae (11176977), Pseudomonas aeruginosa(11093627) as $\mathrm{G}^{-} \mathrm{ve}$ bacteria, and Staphylococcus aureus (MRSA) (11182821) as $\mathrm{G}^{+}$ve bacteria were prepared to be examined using SEM, according to a method of Afrikian, et al., (1973) as follows: 1) Inoculate NB medium tube with bacteria isolated from bloodstream as a control. 2) Incubate inoculated tubes for 18 hours at $37^{\circ} \mathrm{C}$. 3). Recultivate isolated bacteria in the same medium for two hours to have bacteria in log phase. 4) Centrifuge the medium at $224 \times g$ for 3 minutes in order to have the bacterial cells and get rid of the medium.

\section{Evaluation of the Antibacterial Potential of AuNPs}

To determine the antibacterial effects of AuNPs on the tested bacteria, the inhibition zone were divided according to (Barry, et al., 1986) where vancomycin (VA) disks as a standard for $\mathrm{G}^{+} \mathrm{ve}$ and antibiotic imipenem (IP) as a standard for $\mathrm{G}^{-} v \mathrm{ve}$ bacteria PRIMAXIN® I.M. (2009). According to the previous references the following scales were used in the present study: 1) Weekly effect for AuNPs (resistant for antibiotics) which ranging from $(\leq 10 \mathrm{~mm})$ in diameter, Intermediate effect which ranging from (>10 to $14 \mathrm{~mm}$ ) in diameter and Highly effect for AuNPs (sensitive for antibiotics) which ranging from $(>14 \mathrm{~mm})$ in diameter for $\mathrm{G}^{+} \mathrm{ve}$ bacteria from for $\mathrm{G}^{-} \mathrm{ve}$ bacteria. 2) Weekly effect for AuNPs (resistant for antibiotics) ranging from (4 to $\leq 8 \mathrm{~mm}$ ) in diameter, Intermediate effect ranging from $(>8$ to $15 \mathrm{~mm}$ ) in diameter and High effect for AuNPs (sensitive for antibiotics) ranging from $>15 \mathrm{~mm}$ for $\mathrm{G}^{-} v e$ bacteria.

\section{Mountain of Bacteremia Isolates for SEM Examination}

Fixation: 1) Place bacterial cells in the initial fixation solution (2\% Sodium, 2.5\% Glutaraldehyde, Paraformaldehydehyde $\mathrm{pH} 7.4-0.1 \mathrm{M}$, Cacodylate Buffer) for 24 hours at a temperature of $4^{\circ} \mathrm{C}$. 2) Wash the bacterial cells for three times in a buffer solution for 15 
min. in each time. 3) Place bacterial cells in a secondary fixation solution (1\% of Osmium Tetroxide) for an hour at a temperature of $4^{\circ} \mathrm{C}$.

Dehydration: 1) Pass the bacterial cells in an ascending series of a gradual concentration ethanol $(30 \%, 50 \%$, $70 \%, 90 \%$, and 95\%). 2) Move the bacterial cells to an absolute ethanol for $30 \mathrm{~min}$. during that ethanol was changed twice. 3) After each addition of solutions the centrifugation for bacterial cells with different solutions was done at $224 \times g$ for 3 minutes. 4) Use Millipore filter in diameter $0.2 \mathrm{~mm}$ to hold the bacterial cells and get rid of the solution.

Drying: 1) Use the critical point drying method by using (SAMDRI-PVT-3B) equipment. 2) Move the bacterial cells which were dried by the critical point method to the samples (bacterial cells) on filter paper and then stick attach them to the holder by the conducting silver paint. 3) Cover the bacterial cells that aimed to be examined by a thin layer of $\mathrm{Au}$ as a conducting material using the vacuum evaporation machine (Fine Coat Ion Sputter JCF-1100), at 1200 volt.

Observation: Examine the bacterial cells by using JEOL JSM-6360LV Scanning Electron Microscope at magnification (15.000 X).

\section{Statistical analysis}

Data was analyzed by SPSS (2006) Program: 1) Frequencies and percentages. 2) Averages and standard variations. 3) Variations analysis. 4) Dunkin test.

\section{RESULTS AND DISCUSSION}

\section{Results}

\section{Antibiotic Sensitivity Pattern of Bacteremia Isolates}

From Table (1) the result for the G-ve bacteria sensitivity towards tested antibiotics could be summarized as follows:

- E. $\operatorname{coli}_{(11093623) \&(11161644)}$ showed resistance 'R' response towards all tested antibiotics, and intermediate 'I' response against only one antibiotic $\mathrm{c}_{(\mathrm{CN})}$.

- P. aeruginosa $a_{(11093627)}$ \& (11132667) showed 'R' response against 7 antibiotics(FOX, AN, PIP, NOR, CRO, ATM \& CAZ), 'I' response against 4 tested antibiotics $(\mathrm{CN}$, TOB, IPM \& CIP).
- P. fluorescens (11193865) was 'R' against 4 antibiotics ${ }_{(\mathrm{CXM}}$, ATM, CAZ \& FM), sensitive 'S' against 5 antibiotics (AN, TOB, NOR, OFX \& SXT) and 'I' response for the rest of antibiotics.

- K. oxytoca $_{(11102476)}$ was 'R' to antibiotic $(\mathrm{AMP})$ and it was 'S'/I' to the rest of antibiotics.

- Isolates of K. pneumoniae $(11176977) \&(11232940)$ were 'S' response against 6 antibiotics (NOR, CRO, CIP, CAZ, OFX \& sXT), 'R' response against 5 antibiotics (AMP, PIP, TOP, IPM \& FM) and gave 'I' response for the rest of antibiotics. While, K. pneumoniae ${ }_{(11179803)}$ showed 'S' response against 6 antibiotics (AN, PIP, NOR, OFX, SXT \& FM), 'I' response against 4 antibiotics $(\mathrm{CN}, \mathrm{LVX}, \mathrm{CIP} \& \mathrm{CZ})$ and ' $\mathrm{R}$ ' response for the rest (10 out of 20) of antibiotics.

- Acinetobacter baumanii ${ }_{(11109045)}$ showed 'R' response against 4 antibiotics $(\mathrm{TOB}, \mathrm{CXM}$, ATM \& $\mathrm{FM})$, 'S' response against 7 antibiotics (AMP, AN, NOR, CIP, CAZ, OFX \& NA) and 'I' response for the rest of antibiotics.

- Stenotrophomonas maltophilia ${ }_{(11108778)}$ showed 'R' response against 6 antibiotics (AMP, CXM, ATM, CAZ, AMC \& FM), 'S' response against 7 antibiotics (AN, NOR, LVX, CIP, $\mathrm{OFX}, \mathrm{CZ} \& \mathrm{NA}$ ) and 'I' response for the rest of antibiotics.

- Salmonella sp.(11120629) showed 'R' response against only one antibiotic ${ }_{(\mathrm{IPM})}$, showed 'I' response against 7 tested antibiotics(CN, PIP, LVX, CRO, CXM, ATM \& NA) and 'S' response against 11 out of 19 antibiotics.

- E. cloacae $_{(11159053)}$ showed 'R' response against 3 antibiotics (AMP, AMC \& FM) and showed 'S' response

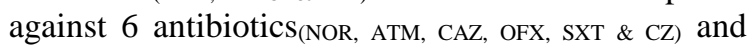
showed 'I' response for the rest of antibiotics.

- C. freundii $(11176991) \&(11182565)$ showed 'R' response against 4 antibiotics(AMP, FOX, AMC \& CZ), 'S' response against 7 antibiotics (AN, NOR, CRO, IPM, CAZ, SXT \& FM) and 'I' response for the rest of antibiotics.

The result for the $\mathrm{G}^{+}$ve bacteria sensitivity towards tested antibiotics recorded in Table (2). S. aureus $(\text { MRSA })_{(11182821)}$ showed 'S' response against 2 antibiotics $_{(\mathrm{OX} \& \mathrm{CZ})}$, 'R' response against 9 antibiotics $(\mathrm{P}$, FOX, CIP, CRO, AMC, OFX, NOR, NA \& CF) and 'I' response for the rest of antibiotics (APM, VA, CXM, CN, SXT, AN \& FM). 
Table 1. The sensitivity of G-ve bacteria isolated from bloodstream to different antibiotics

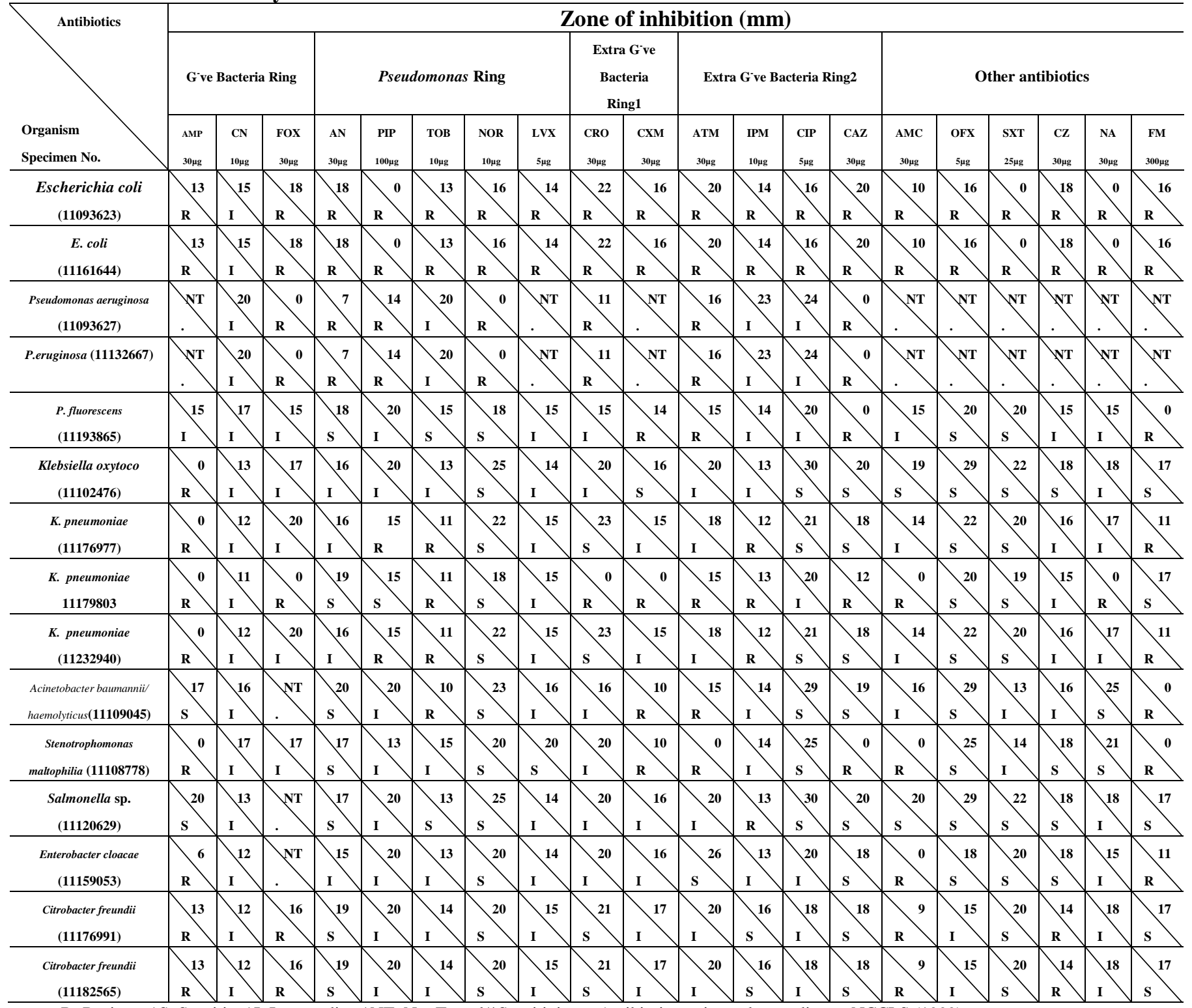

R: Resistant/ S: Sensitive/ I: Intermediate/ NT: Not Tested/*Sensitivity to Antibiotics estimated according to NCCLS (1999)

Table 2. The sensitivity of $\mathrm{G}^{+} \mathrm{ve}$ bacteria isolated from bloodstream to different antibiotics

\begin{tabular}{|c|c|c|c|c|c|c|c|c|c|c|c|c|c|c|c|c|c|c|}
\hline \multirow{2}{*}{$\begin{array}{l}\text { Antibiotics } \\
\text { Organism } \\
\text { Specimen No. }\end{array}$} & \multicolumn{2}{|c|}{$G^{+} v e$ Ring } & \multicolumn{4}{|c|}{$\begin{array}{c}\text { Staphylococcus } \\
\text { Extra Ring }\end{array}$} & \multicolumn{3}{|c|}{$\begin{array}{c}\text { Streptococcus Extra } \\
\text { Ring }\end{array}$} & \multicolumn{9}{|c|}{ Other antibiotics } \\
\hline & $\begin{array}{l}\text { AMP } \\
10 \mu \mathrm{g}\end{array}$ & $\begin{array}{c}P \\
1 \mu g \\
\end{array}$ & 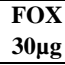 & $\begin{array}{l}\text { CIP } \\
5 \mu \mathrm{g}\end{array}$ & $\begin{array}{c}\text { VA } \\
\text { 30 } \mu \mathrm{g}\end{array}$ & $\begin{array}{l}\text { CXM } \\
\text { 30 } \mu \mathrm{g}\end{array}$ & $\begin{array}{l}\text { CRO } \\
\text { 30 } \mu \mathrm{g}\end{array}$ & $\begin{array}{c}\mathrm{CN} \\
10 \mu \mathrm{g}\end{array}$ & $\begin{array}{l}\text { OX } \\
1 \mu \mathrm{g}\end{array}$ & $\begin{array}{l}\text { AMC } \\
30 \mu \mathrm{g}\end{array}$ & $\begin{array}{c}\text { OFX } \\
5 \mu \mathrm{g}\end{array}$ & $\begin{array}{l}\text { SXT } \\
25 \mu \mathrm{g}\end{array}$ & $\begin{array}{c}\text { AN } \\
\text { 30 } \mu \mathrm{g}\end{array}$ & $\begin{array}{c}\mathrm{CZ} \\
30 \mu \mathrm{g}\end{array}$ & $\begin{array}{l}\text { NOR } \\
10 \mu \mathrm{g}\end{array}$ & $\begin{array}{c}\text { NA } \\
\text { 30 } \mu \mathrm{g}\end{array}$ & 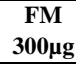 & 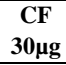 \\
\hline $\begin{array}{l}\text { Staphylococcus } \\
\text { aureus }\end{array}$ & & 13 & & 0 & 20 & 27 & 0 & 20 & 30 & 10 & 0 & & 18 & 28 & 0 & 0 & 20 & 0 \\
\hline
\end{tabular}

R: Resistant/ S: Sensitive/ I: Intermediate/*Sensitivity to Antibiotics estimated according to NCCLS (1999) 


\section{AuNPs Studies}

UV-visible spectral analysis (Figure 1) shows the absorption spectra of the prepared Spherical-AuNPs, which have one absorption band at approximately 520 nm.

The absorption spectrum of Rod-AuNPs is characterized by two bands. The short-wavelength band is located at around $520 \mathrm{~nm}$ (Figure 2).

In metal NPs, the conduction band and valence band lie very close to each other in which electrons move freely. Small spherical-NPs $(<20 \mathrm{~nm})$ exhibit a single surface plasmon band. The absorption peak called

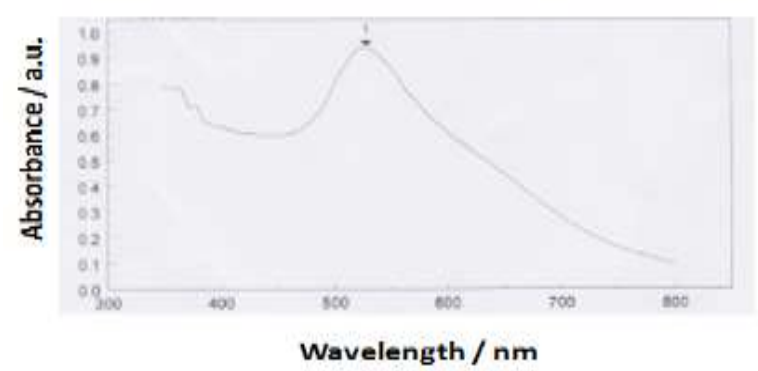

Fig. 1. UV - Visible spectra of Spherical - Gold Nanoparticles (Spherical - AuNPs) surface plasmon resonance (SPR) is obtained in the visible range at $410 \mathrm{~nm}$ in Figure (3).

\section{Transmission Electron Micrograph (TEM) of AuNPs}

Images of the synthesized AuNPs shown in Figure (4) were taken by a TEM and used in measuring the size of Spherical-AuNPs $7.11 \mathrm{~nm}$. Images of the synthesized Rod-AuNPs shown in Figure (5) were taken by a TEM and used in measuring the size and aspect ratio of length to width of the Rod-AuNPs. The average size was 20.7 $\mathrm{nm}$ in width and $103.2 \mathrm{~nm}$ in length and the average aspect ratio was $\sim 4.9$.

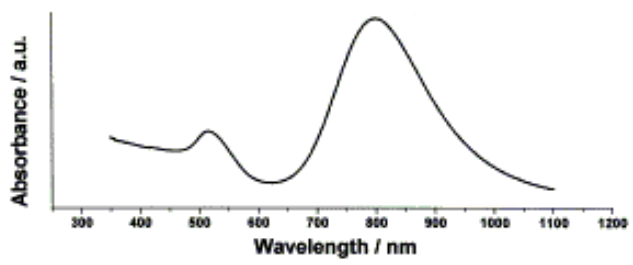

Fig. 2. The absorption spectra for Rod-Gold Nanoparticles (Rod-AuNPs) of average aspect ratios. The longitudinal surface plasmon absorption band of RodAuNPs from 500-900nm

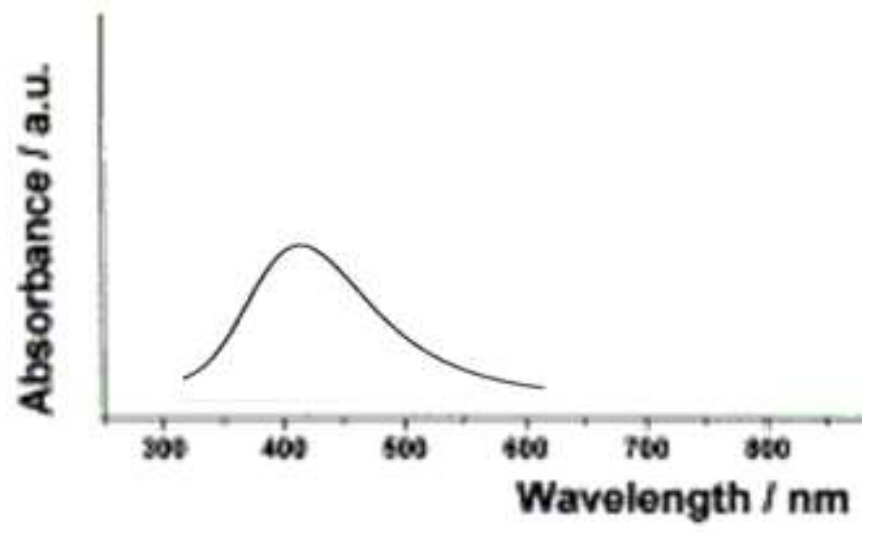

Fig. 3. UV- Visible absorption spectra of small Spherical- Nanoparticles (Spherical-NPs) 


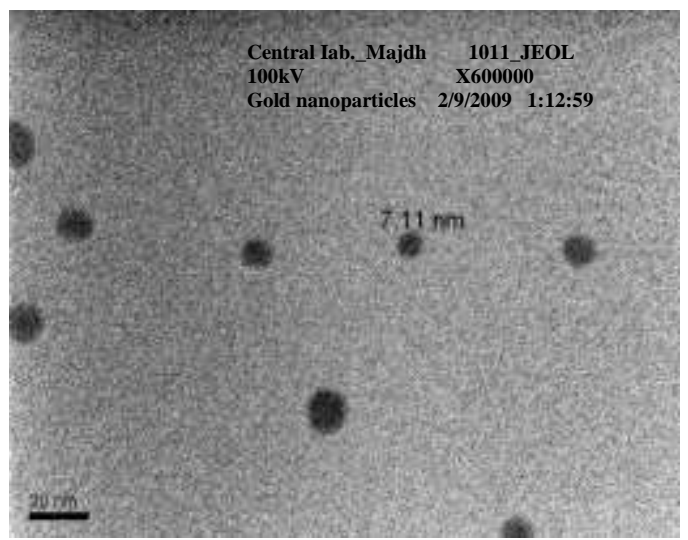

Fig. 4. Transmission Electron Microscopy (TEM) image of spherical-AuNPs

\section{Antibacterial Activity of AuNPs}

The results of sensitivity pattern of $\mathrm{G}^{-} \mathrm{ve}$ and $\mathrm{G}^{+} \mathrm{ve}$ bacteria to AuNPs were recorded in Table (3). Each of Rod-AuNPs and Spherical-AuNPs appeared high effect

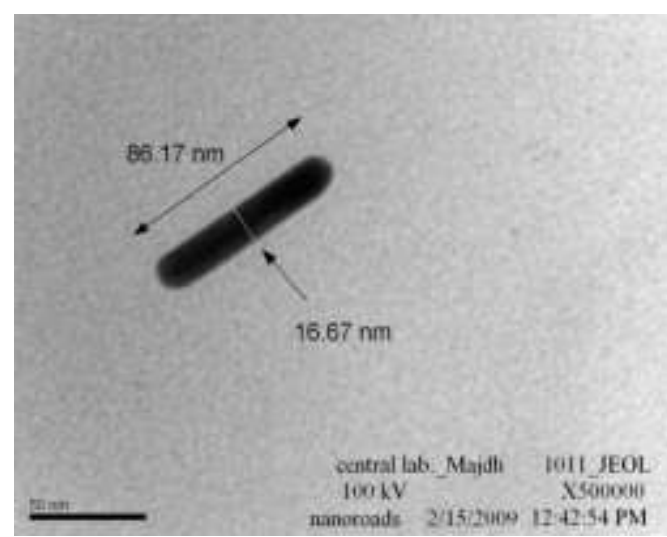

Fig. 5. Transmission Electron Microscopy (TEM) image of Rod-Gold Nanoparticles (Rod-AuNPs)

of all tested isolates of either $\mathrm{G}^{-} \mathrm{ve}$ or $\mathrm{G}^{+} \mathrm{ve}$ bacteria. In another meaning, tested isolates of multidrug-resistant bacteremia exhibited sensitivity to two types of AuNPs.

Table 3. Sensitivity pattern of G've and G+ve Bacteria to AuNPs

\begin{tabular}{|c|c|c|c|}
\hline \multirow{2}{*}{\multicolumn{2}{|c|}{$\begin{array}{ll}\text { Grve bacteria (No. of Specimen) } & \text { NPs }\end{array}$}} & \multicolumn{2}{|c|}{ Zone of inhibition (diameter $\mathrm{mm}$ ) } \\
\hline & & Rod-AuNPs & Spherical-AuNPs \\
\hline \multirow{15}{*}{ G`ve } & Escherichia coli $_{(11093623)}$ & 26 & 28 \\
\hline & E. $\operatorname{coli}_{(11161644)}$ & 25 & 26 \\
\hline & P. aeruginosa ${ }_{(11093627)}$ & 25 & 26 \\
\hline & Pseudomonas aeruginosa ${ }_{(11132667)}$ & 25 & 28 \\
\hline & P. fluorescens /putida ${ }_{(11193865)}$ & 26 & 28 \\
\hline & Klebsiella oxytoca $_{(11102476)}$ & 26 & 28 \\
\hline & Klebsiella pneumoniae $_{(11176977)}$ & 24 & 25 \\
\hline & K. pneumoniae $(11179803)$ & 25 & 22 \\
\hline & K. pneumoniae $(11232940)$ & 26 & 40 \\
\hline & Acinetobacter baumanni $_{(11109045)}$ & 25 & 27 \\
\hline & Stenotrophomonas maltophilia $_{(11108778)}$ & 27 & 21 \\
\hline & Salmonella sp. (11120629) & 25 & 29 \\
\hline & Enterobacter cloacae $_{(11159053)}$ & 25 & 27 \\
\hline & Citrobacter freundii ${ }_{(11176991)}$ & 24 & 27 \\
\hline & C. freundii $(11182565)$ & $26 \quad \mathrm{~S}$ & 27 \\
\hline $\mathrm{G}^{+} \mathrm{ve}$ & Staphylococcus aureus (MRSA) $)_{(11182821)}$ & $25 \quad * * S$ & 29 \\
\hline
\end{tabular}

For Gve Bacteria: Sensitive $(* \mathrm{~S})=>15 \mathrm{~mm}$ in diameter, Resistance $(\mathrm{R})=\leq 4-8 \mathrm{~mm}$ in diameter, according to PRIMAXIN@ I.M (2009)/ For G ${ }^{+} v e$ Bacteria: ${ }^{* *} \mathrm{~S}=\leq 10$ for week effect, according to (Barry, et al., 1986) 


\section{Evaluation of the Bacteriostatic/Bactericidal Aspect after Exposure to AuNPs}

To detect the Bacteriostatic (BS)/bactericidal (BC) aspect of AuNPs towards bacterial isolates from bloodstream, re-inoculation the bacterial cells from zone of inhibition on N.A. was performed. The data were recorded according to growth (BS) on N.A. or nongrowth (BC) on N.A. Table (4) revealed that RodAuNPs gave BS effect against the isolates of $P$. aeruginosa (11093627\&11132667), E. cloacae(11159053), $C$. freundii(11176991\&11182565), and it gave BC effect against the rest of isolates. Spherical-AuNPs gave BS effect against all tested isolates. In case of $\mathrm{G}^{+} \mathrm{ve}$ bacteria the Rod-AuNPs gave BC effect against $S$. aureus (MRSA) (11182821), while, Spherical-AuNPs gave BS effect against the same isolate (MRSA).

Effects of AuNPs on bloodstream bacteria as demonstrated by SEM examination

After examining different bacteria using SEM it can be concluded that:

The scanning electron micrograph of non-treated $E$. coli(11161644) cells showed straight rods occur singly, Figure (6a), on the other hand E. coli cells after treatment by Rod-AuNPs, for $18 \mathrm{~h}$ showed crease on some cells walls, Figure (6b). The other micrograph for $E$. coli cells after treatment by Spherical-AuNPs, showed some deformities in the external shape of cells, exit of the components of some cells and decreasing number of bacterial cells, Figure (6c).

The scanning electron micrograph of non-treated $K$. pneumonia $_{(11176977)}$ bacteria showed straight rods arranged singly, Figure (7a), but the treated with RodAuNPs and Spherical-AuNPs, showed some crease of cells walls with some deformities in the external shape of cells Figure $(7 b, c)$.

The scanning electron micrograph of non-treated $P$. aeruginosa $a_{(11093627)}$ bacteria showed straight rods or slightly curved rods, Figure (8a), but the micrograph of $P$. aeruginosa after treatment with Rod-AuNPs, showed exit of the components of some cells, Figure (8b). The other micrograph for $P$. aeruginosa cells after treatment by Spherical-AuNPs, observed some shortness of cells with some deformities in the external shape of cells and crease on some cells walls (Figure 8c).

The scanning electron micrograph of non-treated Methicillin resistant $S$. aureus (MRSA)(11182821) showed spherical cells in irregular clusters, Figure (9a). Bacterial cell of (MRSA) after treated by Rod-AuNPs, showed full lyses of bacterial cells, Figure (9b). The other micrograph for MRSA bacterial cells after treated by Spherical-AuNPs, showed some appendages on bacterial cell wall, some deformities in the external shape of cells and decreasing number of bacterial cells, Figure $(9 \mathrm{c})$.

Table 4. Determination of bacteriostatic/bactericidal effects of AuNPs against G've and G+ve Bacteria isolated from bloodstream

\begin{tabular}{|c|c|c|c|}
\hline Bacteria & No. of Specimen & Rod-AuNPs & Spherical-AuNPs \\
\hline \multirow{15}{*}{ Grve } & Escherichia coli $_{(11093623)}$ & $\mathrm{BC}$ & $\mathrm{BS}$ \\
\hline & E. $\operatorname{coli}_{(11161644)}$ & $\mathrm{BC}$ & BS \\
\hline & Pseudomonas aeruginosa $_{(11093627)}$ & BS & $\mathrm{BS}$ \\
\hline & P. aeruginosa $(11132667)$ & $\mathrm{BS}$ & BS \\
\hline & P. fluorescens/putida $(11193865)$ & $\mathrm{BC}$ & BS \\
\hline & Klebsiella oxytoca $_{(11102476)}$ & $\mathrm{BC}$ & BS \\
\hline & Klebsiella pneumoniae $_{(11176977)}$ & $\mathrm{BC}$ & BS \\
\hline & K. pneumoniae $(11179803)$ & $\mathrm{BC}$ & BS \\
\hline & K. pneumoniae $(11232940)$ & $\mathrm{BC}$ & BS \\
\hline & Acinetobacter baumanni $_{(11109045)}$ & $\mathrm{BC}$ & BS \\
\hline & Stenotrophomonas maltophilia $(11108778)$ & $\mathrm{BC}$ & BS \\
\hline & Salmonella sp. (11120629) & $\mathrm{BC}$ & BS \\
\hline & Enterobacter cloacae (11159053) & BS & BS \\
\hline & Citrobacter freundii ${ }_{(11176991)}$ & $\mathrm{BS}$ & BS \\
\hline & C. freundii $(11182565)$ & $\mathrm{BS}$ & BS \\
\hline $\mathrm{G}^{+} \mathrm{ve}$ & Staphylococcus aureus $(\mathrm{MRSA})_{(11182821)}$ & $\mathrm{BC}$ & $\mathrm{BS}$ \\
\hline
\end{tabular}

$\mathrm{BS}=$ Bacteriostatic effect, $\mathrm{BC}=$ Bactericidal effect 


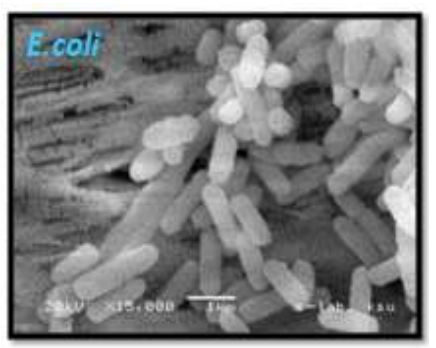

(a)

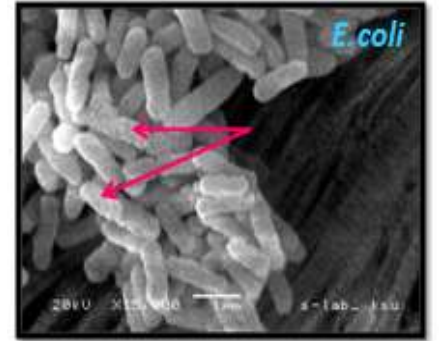

( b )

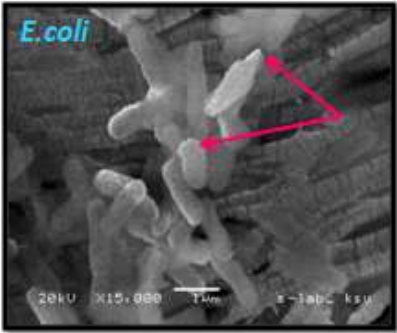

(c)

Fig.6. Scanning electron micrograph (SEM) of E. coli $(11161644)$ mounted on filter paper from bloodstream, (a) Non treated bacterial cell of $E$. coli showed straight rods occur singly; (b) cell of $E$. coli after treated by Rod-AuNPs, which illustrated crease on some cells walls and (c) bacterial cells of $E$. coli after treated with Spherical-AuNPs, showed some deformities in the external shape of cell, exit of the components of some cells and decreasing number of bacterial cells

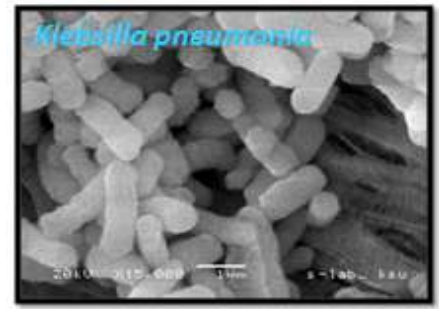

(a)

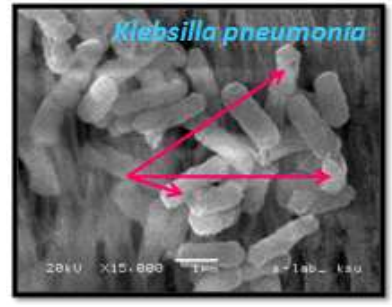

( b )

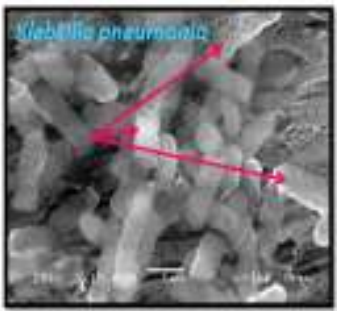

(c)

Fig. 7. Scanning electron micrograph (SEM) of K. pneumonia(11176977) mounted on filter paper from bloodstream, (a) Non treated bacterial cell of $K$. pneumonia showed straight rods arranged singly; (b) bacterial cells of $K$. pneumonia after being treated with Rod-AuNPs and (c) after treatment with Spherical-AuNPs which illustrated some crease of cells walls with some deformities in the external shape of cells

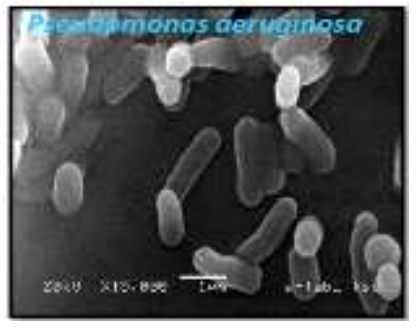

( a )

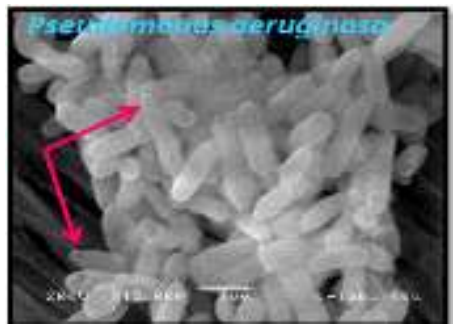

( b )

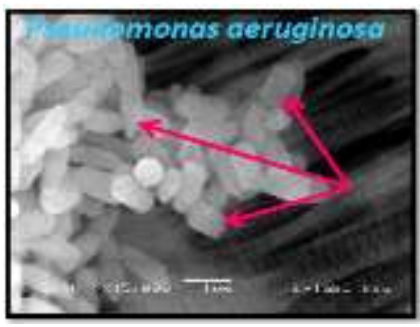

(c)

Fig. 8. Scanning electron micrograph (SEM) of $P$. aeruginosa $a_{(11093627)}$ mounted on filter paper from bloodstream, (a) Non treated bacterial cell of $P$. aeruginosa showed straight rods or slightly curved rods; (b) bacterial cell of $P$. aeruginosa after being treated with Rod-AuNPs, which illustrated exit of the components of some cells and (c) bacterial cells of $P$. aeruginosa after treatment with Spherical-AuNPs, showed some shortness of cells with some deformities in the external shape of cells and crease on some cells walls

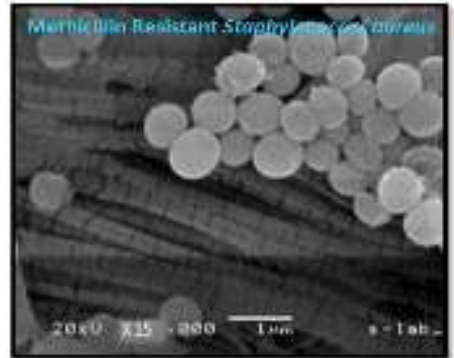

( a )

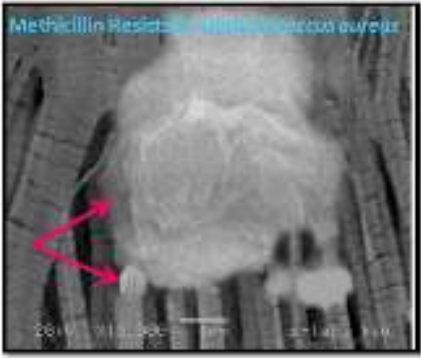

( b )

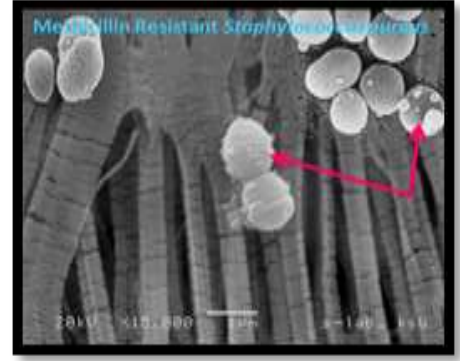

(c)

Fig. 9. Scanning electron micrograph (SEM) of Methicillin Resistant S. aureus (MRSA)(11182821) mounted on filter paper from blood stream (a) Non treated bacterial cell of MRSA showed spherical cells in irregular clusters; bacterial cell of MRSA after treated (T) with filtered Rod-AuNPs, (b) illustrated full lyses of bacterial cells, some deformities in the external shape of cell and lyses of bacterial cell wall and (c) bacterial cells of MRSA after treatment with SphericalAuNPs, showed some appendages on bacterial cell wall, some deformities in the external shape of cells and decreasing number of bacterial cells 


\section{Discussion}

Sixteen samples from infected bloodstream were taken from Security Forces Hospital in Riyadh, Saudi Arabia. The sensitivity of isolated $\mathrm{G}^{-} \mathrm{ve}$ bacteria for commercial antibiotics was tested: The data of $\mathrm{G}^{-} \mathrm{ve}$ bacteria of isolates $E$. $\operatorname{coli}_{(11093623 \& 11161644)}$ were 'R' to 19 out of 20 tested antibiotics. Similar results were obtained by Shehabi, et al. (2004) and Alhashash, et al. (2013), who illustrated that a significant increase in the resistance to antibiotics was observed in E. coli bacteremia.

Data from present study revealed that isolates of $P$. aeruginosa were ' $\mathrm{R}$ ' to 7 out of 11 tested antibiotics particularly antibiotic $(\mathrm{CAZ})$. Shenoy, et al., (2002) disagreed with our results which revealed that $P$. aeruginosa isolate was ' $\mathrm{S}$ ' to antibiotic $\mathrm{C}_{(\mathrm{CAZ})}$ and they agreed with our findings that the isolate was resistant to antibiotic $_{(\mathrm{PIP})}$.

Tested isolates of $K$. pneumoniae were differentiate ' $\mathrm{R}$ ' from 5 to 10 towards tested antibiotics, and were 'S'/I' to the rest. These findings were in agreement with the results obtained by Stock and Wiedemann (2001).

The isolate $A$. baumannii ${ }_{(11109045)}$ was 'I' to antibiotic $_{(\mathrm{PIP})}$, this result was in disagreement with Montero, et al. (2004) who confirmed that antibiotic $(\mathrm{PIP})$ can still be the best alternative for carbapenemresistant $A$. baumannii infections.

In case of Salmonella $\mathrm{sp}_{\text {(11120629) }}$ it was sensitive to 11 out of 19 tested antibiotics e.g. (AMP AN, CIP, SXT). While, White, et al., (2001) reported that Salmonella sp. isolates were ' $\mathrm{R}$ ' to antibiotics (AMP, SXT) and all isolates of Salmonella sp. were 'S' to antibiotics(AN, CIP). Vice versa, $C$. freundii $(11176991 \& 11182565)$ was 'S' to 7 out of 20 antibiotics, including antibiotic $(\mathrm{IPM})$. This result was compatible with that of Valencia et al. (1994).

The results of $S$. maltophilla (11108778) $_{1}$ and $S$. aureus (MRSA) in sensitivity to antibiotics are in consistent with previous studies, Çıkman, et al. (2016) and Gu, et al. (2020) respectively, who revealed that association of these isolates with multidrug-resistance is common.

In general, the study of sensitivity to antibiotics showed compatibility and incompatibility with previous studies for one or more antibiotics.

Although the mechanisms of antibiotics include interference with cell wall synthesis, inhibition of protein synthesis, interference with nucleic acid synthesis, inhibition of a metabolic pathway, and disruption of bacterial membrane structure, bacteria may show resistance to one or more classes of antimicrobial agents, or may acquire resistance by de novo mutation or via the acquisition of resistance genes from other organisms (Tenover, 2006).
UV-visible spectral analysis for AuNPs, indicated that the absorption spectra of the prepared SphericalAuNPs. Based on the absorption spectra it is clear that spherical metallic particles show only one absorption band owing to what is called SPR. The wavelength of the SPR of metal particles depends on the particle size and the dielectric constant of the metal itself. This strong absorption is due to the oscillation of the surface electron around the ionic core once it is exposed to visible light. Spherical-AuNPs have one absorption band at approximately $520 \mathrm{~nm}$.

The absorption spectrum of Rod-AuNPs is characterized by two bands. The short-wavelength band is located at around $520 \mathrm{~nm}$ and is attributed to the transverse SPR. This band has some contribution from the Spherical-AuNPs present in the solution, and it shifts only slightly to shorter wavelength with increasing the average aspect ratio of the nanorods. The maximum of the second absorption band appears at longer wavelength and corresponds to the longitudinal SPR and increases with increasing the aspect ratio.

Wound and burn bacteria can frequently colonize and proliferate in the exposed tissues and, when established, these bacteria can pass through the blood capillaries of the tissues, which may eventually lead to bacteremia. Once the bacteremia phases are reached, infections from burns or wounds become untreatable by traditional antibiotic treatments (Vivas, et al., 2019).

For the Spherical-AuNPs and Rod-AuNPs the result showed that all tested $\mathrm{G}^{-} \mathrm{ve}$ and $\mathrm{G}^{+} \mathrm{ve}$ isolates were sensitive to the treatment. To detect antibacterial activity of different shapes of AuNPs against isolated bacteria from bloodstream, Rod and Spherical-AuNPs were tested.

Spherical-NPs have bacteriostatic effect against all tested $\mathrm{G}^{-} \mathrm{ve}$ and $\mathrm{G}^{+} \mathrm{ve}$ bacteria. AuNPs were effective against all tested $\mathrm{G}^{-}$ve bacteria, while the AgNPs were different in their antibacterial activity against tested $\mathrm{G}^{-}$ ve bacteria except one isolate of $K$. pneumoniae (11176977) (Alsayed, et al., 2015). This result was in disagreement with Helmstetter (2010) who revealed that the Au and AgNPs they used to be active against $\mathrm{G}^{+} v e$ bacteria and $\mathrm{G}^{-} \mathrm{ve}$ ones.

The difference between tested NPs in their antibacterial activity against either $\mathrm{G}^{-} v e$ or $\mathrm{G}^{+} \mathrm{ve}$ bacteria in the present study may be due to general physiological differences in the cell wall membrane constitution of $\mathrm{G}^{-} \mathrm{ve}$ and $\mathrm{G}^{+} \mathrm{ve}$ bacteria. Suffredini et al. (2006) and Joy et al. (2007) confirmed that the G've bacteria, perhaps due to their external lipopolysaccharide structure, the peptidoglycan layer is a specific membrane feature of bacterial species, were more resistant to antibiotics, which can explain why 
$\mathrm{G}^{+} \mathrm{ve}$ bacteria were more sensitive to studied $\mathrm{Au}$ and AgNPs than G-ve bacteria. Amro et al. (2000) suggested that metal depletion may cause the formation of irregularly shaped pits in the outer membrane and change membrane permeability, which is caused by progressive release of lipopolysaccharide molecules and membrane proteins.

Rod-AuNPs would be drawn to the negative membrane, whereas Sperical-AuNPs would not be attracted as strongly. Once bound to the cell, the amphiphilicity of the mixed monolayer of Rod-AuNPs could induce a variety of further interactions. The toxicity of the AuNPs is related to their interactions with the cell membrane, a feature initially mediated by their strong electrostatic attraction to the negatively charged bilayer (Goodman et al., 2004).

Studying the external shape of some isolated bacteria after exposure to Rod-AuNPs for 18 hours using the scanning electron microscope showed crease on some cells walls of $E$. coli cells(11161644), while the same isolate of E. coli after treatment by SphericalAuNPs showed some deformities in the external shape of cell and exit of the components of some cells, comparing to the non-treated cells of the same species (Nanninga, 1998).

Cells of $P$. aeruginos $(11093627)$ after being treated with Rod-AuNPs, showed exit of the components of some cells, while the same isolate after treatment by Spherical-AuNPs showed some shortness of cells with some deformities in the external shape of cells and crease on some cells walls. Brock and Madigan (2006), explained why is the deformities in the external shape of cells attributed to contain a high concentration of dissolved solutes in cells, as a considerable turgor pressure to develop about 2 atmospheres in a bacterium, and this is roughly the same as pressure in an automobile tire.

Treated cells of Methicillin resistant S. aureus $(\text { MRSA })_{(11182821)}$ with Rod-AuNPs illustrated full lyses of bacterial cells. But MRSA cells after treatment by Spherical-AuNPs showed some appendages on bacterial cell wall, some deformities in the external shape of cells and decreasing number of bacterial cells. Voet and Voet (1995) explained one mechanism anticipated to be similar in comparing the Bacteria and Eukarya samples is membrane adhesion or cell lysis by the NPs.

The lyses of some isolated bacteria from bloodstream after treatment with AuNPs refer to unbalance incidence between two groups of enzymes, hydrolases and synthases in favor of hydrolyses enzymes which performs cells lyses. Decrease in diameter of Staphylococcus sp. after treatment with AuNPs become of some defecting in the syntheses enzymes which are responsible for insertion of new subunits into the murein net (Holtje, 1998).

With limited antibiotic options and an escalating bacterial resistance there is an urgent need to explore alternative ways of meeting this global challenge. The field of medical nanotechnology has emerged as an innovative and a powerful tool for treating some of the most complicated health conditions. Different inorganic NPs including gold and others have showed potential antibacterial efficacies. Interestingly, AuNPs have gained specific attention, due to their biocompatibility, ease of surface functionalization, and their optical properties (Okkeh, et al. 2021).

From results obtained, it can be concluded that the nanostructures and morphologies of AuNPs may offer new possibilities for promising therapeutic applications of multidrug-resistance bacteremia.

\section{REFERENCES}

Alhashash, F., V. Weston, M. Diggle and A. McNally. 2013. Multidrug-Resistant Escherichia coli Bacteremia. Emerg Infect Dis. 19(10): 1699-1701. doi: 10.3201/eid1910.130309

Alsayed, M. F. S., A. A. Shoeib, A. A. Hindi, M. A. Awad and K. D. M. O. Ortashi. 2015. Synthesis of silver nanoparticles Discourage the growth of isolated bacteria invading the blood stream. Digest J. of Nanomaterials and Biostructures. 10 (2): 385-392.

Afrikian, E. G., G. St. Julian, and A. B. Jr. Lee. 1973. Scanning electron microscopy of bacterial colonies. Appl. Microbiol. 26(6): 934-937.

Amro, N. A., L. P. Kotra, K. Wadu-Mesthrige, A. Bulychev, S. Mobashery and G. Liu. 2000. High-resolution atomic force microscopy studies of the Escherichia coli outer membrane: structural basis for permeability. Langmuir. 16:2789-2796.

Aramburu, C. S., N. Harbarth, M. Liassine, A. Girard, J. Gervaix, G. Scherenzel, P. S. Renzi. 2006. Communityacquired Methicillin-Resistant Staphylococcus aureus in Switzerland. Euro Surveill. 11(1):42-43.

Azu, N. and R. Onyeagba. 2007. Antimicrobial properties of extracts of Allium cepa (Onions) and Zingiber officinale (Ginger) on Escherichia coli, Salmonella typhi and Bacillus subtilis. The Internet J. of Tropic. Medicine. 3 (2).

Barry, A. L., C. Thornsberry and R. N. Jones. 1986. Evaluation of teicoplanin and vancomycin disk susceptibility tests. J. Of Clinic. Microbi. American Society for Microbiology. 23 (1): 100-103.

Bin, C., W. Hui, Z. Renyuan, N. Yongzhong, X. Xiuli, X. Yingchun, Z. Yuanjue and C. Minjun. 2006. Outcome of cephalosporin treatment of bacteremia due to CTX-M-type extended-spectrum beta-lactamase-producing Escherichia coli. Diagn Microbiol Infect Dis. 56(4):351-7.

Brock, T. D. and M. T. Madigan. 2006. Biology of Microorganism. $11^{\text {th }}$ ed. Prentice- Hall, Inc. pp. 74.

Çıkman, A., M. Parlak, Y. Bayram, H. Güdücüoğlu and M. Berktaş. 2016. Antibiotics resistance of Stenotrophomonas maltophilia strains isolated from various clinical 
specimens. Afr Health Sci. 16(1): 149-152. doi: 10.4314/ahs.v16i1.20

Donnenberg, M. S., C. O. Tacket and S. P. James. 1993. Role of the eaeA gene in experimental enteropathogenic Escherichia coli infection. J Clin Invest. 92:141.

Fowler, G. V., W. H. Boucher, G. R. Corey and E. Abrutyn. 2006. Daptomycin versus standard therapy for bacteremia and endocarditis caused by Staphylococcus aureus. The New England J. of Medicine. 355:653-665.

Frens, G. 1972. Particle size and sol stability in metal colloids. Colloid \& Polymer Sci. 250: 736-741.

Frens, G. 1973. Controlled nucleation for the regulation of the particle size in monodisperse gold suspensions, Nature (London). Phys. Sci. 241: 20-22.

Goodman, M. C., D. C. McCusker, T. Yilmaz and M. V. Rotello. 2004. Toxicity of gold NPs functionalized with cationic and anionic side chains. Bioconjugate Chem. 15: 897-900.

Grisaru-Soen, G., M. G. Wysoki and N. Keller. 2004. Risk factors for development of nontyphoid Salmonella bacteremia. Clinical Pediatrics. 43(9): 825-829.

Gu, F., W. He, S. Xiao and S. Wang. 2020. Antimicrobial resistance and molecular epidemiology of Staphylococcus aureus causing bloodstream infections at Ruijin Hospital in Shanghai from 2013 to 2018. Scientific Reports 10:6019. https://doi.org/10.1038/s41598-020-63248-5

Helmstetter, N. J. 2010. Antimicrobial effects of silver and gold NPs alone, and functionalized with ampicillin. Kalamazoo College, Department of Biological Sciences, Western Michigan University, M.Sc.1-24.

Holtje, J-V. 1998. Growth of the stress-bearing and shape maintaining murein sacculus of Escherichia coli. American society for Microbiology. 62 (1):181-203.

Hung, Su-Hua. 2007. Gold nanoparticle-based immunochromatographic test for identification of Staphylococcus aureus from clinical specimens. Clinica Chimica Acta. 373: 139-143.

Irving, W. H. 2004. Problem-orientated clinical microbiology and infection. J. of Antimicrob. Chemother. 5 (1): 155162.

Javaloyas, M., D. García-Somoza and F. Gudiol. 2003. Bacteremia due to Escherichia coli: epidemiological analysis and sensitivity to antibiotics in a country hospital. Med Clin (Barc). 8.120(4):125-7. doi: 10.1016/s00257753(03)73623-9.

Jigna, P., K. Nehal and C. Sumitra. 2006. Screening of some traditionally used medicinal plants for potential antibacterial activity. Indian J. of Pharmaceutical Sci. 68(6): 832-834.

Joy, B., A. Rajan and E. Abraham. 2007. Antimicrobial activity and chemical composition of essential oil from Hedychium coronarium. Phytother. Res. 21:439-443.

Kaçmaz, B. and A. Aksoy. 2005. Antimicrobial resistance of Enterococci in Turkey. International Journal of Antimicrobial Agents. 25 (6): 535-538.

Kaplan, S. L. and E. O. Jr. Mason. 1998. Management of infections due to antibiotic-resistant Streptococcus pneumoniae. Clin. Microbiol. Rev. 11(4):628-44.

Kimling, J., M. Maier, B. Okenve, V. Kotaidis, H. Ballot and A. Plech. 2006. Turkevich method for gold nanoparticle synthesis revisited. J. Phys. Chem. B. 110: 15700-15707.
Limsuwan, S., S. Subhadhirasakul, S. P. Voravuthikuncha. 2009. Medicinal plants with significant activity against important pathogenic bacteria. Pharmaceutical Biology. 47(8): 683-689.

Montero, A., J. Ariza, X. Corbella and A. Doménech. 2004. Antibiotic combinations for serious infections caused by carbapenem-resistant Acinetobacter baumannii in a mouse pneumonia model. J. of Antimicrobial Chemotherapy. 54(6):1085-91. doi: 10.1093/jac/dkh485.

Mothana, R. A. A. and U. Lindequist. 2005. Antimicrobial activity of some medicinal plants of the island Soqotra. J Ethnopharmacol. 96:177-181.

Mylonakis, E., H. U. G. Chi and A. C. Burke. 2006. Escherichia coli Infections? eMedicine Specialties 10;352(9135):1207-12.

Nanninga, N. 1998. Morphogenesis of Escherichia coli. American society for Microbiology. 62 (1): 101-129.

NCCLS: National Committee for Clinical Laboratory Standards. 1999. Performance Standards for Antimicrobial Susceptibility Testing, M100-S9. Wayne, pa:NCCLS.

Okkeh, M., N. Bloise, E. Restivo, L. De Vita, P. Pallavicini and L. Visai. 2021. Review: Gold nanoparticles: Can they be the next magic bullet for multidrug-resistant bacteria? Nanomaterials.11:312. https://doi.org/10.3390/nano11020312

Podolsky, S. H. 2018. The evolving response to antibiotic resistance (1945-2018). Palgrave Communications 4(124): 1-8. DOI: 10.1057/s41599-018-0181-x

Podschun, R. and U. Ullmann. 1998. Klebsiella spp. as nosocomial pathogens: epidemiology, taxonomy, typing methods, and pathogenicity factors. Clin. Microbiol. Rev. 11:589-603.

PRIMAXIN® I.M. 2009.Imipenem and cilastatin for injectable suspension. pp.1-11.

Ryan, K. J. and C. G. Ray. 2004. Sherris Medical Microbiology, $4^{\text {th }}$ ed., McGraw Hill. ISBN 0-8385-8529-9.

Sau, T. K. and C. J. Murphy. 2004. Seeded high yield synthesis of short $\mathrm{Au}$ nanorods in aqueous solution. Langmuir, 20; 20(15):6414-6420. doi: 10.1021/la049463z.

Shehabi A. A., A. M. Mahafzah and K. Z. Al-Khalili. 2004. Antimicrobial resistance and plasmid profiles of urinary Escherichia coli isolates from Jordanian patients. University of Jordan. 10(3): 322-328.

Shenoy, S., S. Baliga, D. R. Saldanha and H. V. Prashanth. 2002. Antibiotic sensitivity patterns of Pseudomonas aeruginosa strains isolated from various clinical specimens. Indian J. of medical sci. 56(9): 427-430.

Shoeib, A. A. and R. M. S. Alkufeidy. 2014. Bacteriostatic or bactericidal action of four aqueous plant extracts on multidrug resistant bacteremia and their effect on cells morphology recorded using scanning electron microscopy (SEM). African Journal of Microbiology Research. 8(44): 3732-3742.

SPSS: Statistical Package for Social Science. 2006. Guide to data analysis, by M. J. Norus. SPSS Inc, Publisher: Upper Saddle River, N. J., Prentice Hall.

Stock I. and B. Wiedemann. 2001. Natural antibiotic susceptibility of Klebsiella pneumoniae, $K$. oxytoca, $K$. planticola, $K$. ornithinolytica and $K$. terrigena strains. J. Med. Microbiol. 50: 396-406. DOI: 10.1099/0022-131750-5-396. 
Suffredini, I. B., M. L. B. Paciencia, V. A. Drauzio and R. N. Younes. 2006. Antibacterial activity of Brazilian Amazon plant extracts. Brazilian J. of Infectious Diseases 10 (6).

Sun, H. Y., S. Y. Chenb, S. C. Changac and S. C. Pand. 2006. Community-onset Escherichia coli and Klebsiella pneumoniae bacteremia: influence of health care exposure on antimicrobial susceptibility. J. of infection and public health. 55(2):135-141.

Tenover, F. C. 2006. Mechanisms of antimicrobial resistance in bacteria. The American J. of Medicine. 119 (6A):S3S10.

Turkevich, J., P. C. Stevenson and J. Hillier. 1951. A study of the nucleation and growth processes in the synthesis of colloidal gold. Discuss. Faraday. Soc. 1951(11): 55-75.

Valencia, A. M. d. R., A. Vuye and J. Pijck. 1994. Selection of resistant mutants of citrobacter freundii by second and third-generation cephalosporins and imipenem. Infection J. 12(6): 402-404.

Vivas, R., A. A. T. Barbosa, S. S. Dolabela and S. Jain. 2019. Multidrug-resistant bacteria and alternative methods to control them: An overview. Microbial Drug Resistance. 25(6): 890-908. https://doi.org/10.1089/mdr.2018.0319

Volk, W. A., D. C. Benjamin, R. J. Kadner and J. T. Parsons. 1986. Essentials of Medical Microbiology, $3^{\text {rd }}$ edition J. B. LIPPINCOTT COMPANY, pp 823.

Voet, D. and J. G. Voet. 1995. Biochemistry, $2^{\text {nd }}$ edit., John Wiley and Sons, Inc., New York, 1392p. https://doi.org/10.1002/prot.340230421

White, D. G., S. Zhao, R. Sudler and S. Ayers. 2001. The isolation of antibiotic-resistant Salmonella from retail ground meats. The new England J. of medicine. 345(16): 1147-1154.

Wroth, L. J. and M. A. Salvin. 2008. Bloodstream infections in haematology: Risks and new challenges for prevention. Blood Reviews. 23 (2009): 113-122.

Yu, V. L., C. C. Chiou, C. Feldman and A. Ortqvist. 2003. An international prospective study of pneumococcal bacteremia: correlation with in vitro resistance, antibiotics administered, and clinical outcome. Clin Infect Dis. 15:37(2): 230-237. 


\section{الملخص العربي}

\section{تخليق الجزيئات النانوية الكروية//العصوية للأب للتغلب على بكتيرات الام "البكتيريميا" متعددة المقاومة للمضادات الحيوية}

عالية عبد الباقي شعيب، عواطف بنت أحمد بن عبد الرزاق هندي، مشاعل بنت فهد بن سالم السيد

لتحديد التأثير الموقف للنمو/المميث للجزيئات النانو المختلفة. أثتبت الدراسة أن الجزيئات النانوية العصوية للذهب سجلت تأثثر موقف للنمو على كل من Pseudomonas aeruginosa (11093627) \& (11132667), Enterobacter cloacae(11159053) and Citrobacter (11182565), لبقية العزلات المختبرة. كما اظهرت الجزيئات النانوية الكروية للذهب Spherical-AuNPs تأثير موقف لنمو جميع عزلات البكتيريميا متعددة المقاومة المختبرة. كثفت الدراسات الالكتروميكروسكوبية عن تأثنير الجزيئات النانوية، سواء العصوية أو كروية الثكل، على الثكل الخارجي لخلايا Klebsiella g E. coli علات البكتيريميا السالبة لجرام

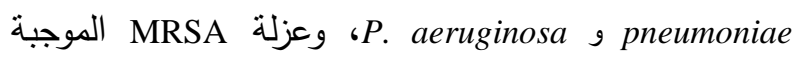
لجرام. يستخلص من النتائج المتحصل عليها أن الجزيئات النانوية للذهب باختلاف الثكل المورفولوجي، قد توفر إمكانيات جديدة للتطبيقات العلاجية الواعدة للعزلات البكتيرية المسببة للبكتيريميا متعددة المقاومة للمضادات الحيوية.
تم جمع 10 عزلة بكتيرية سالبة لجرام وعزلة واحدة موجبة لجرام متعددة المقاومة للمضادات الحيوية، من مجرى الدم من

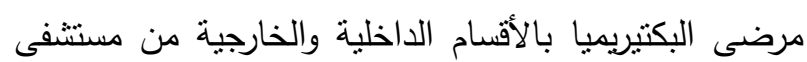
قوى الأمن في الرياض، المملكة العربية السعودية. بدراسة العزلات ذات المقاومة المتعددة للمضادات الحيوية، تم تسجيل عزلتين (11161644)\& E. coli(11093623) كانتا مقاومة لـ 19 من أصل . r مضادا حيويا تم اختباره، باستثناء المضاد

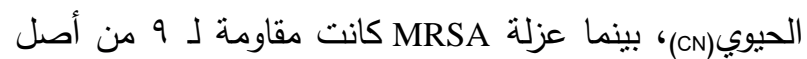
11 مضادا حيويا، وكانت العزلة حساسة للمضادات الحيوية لهينة (AuNPs) • (ox\&cz) لتتبيط نمو عزلات البكتيريميا متعددة المقاومة للمضادات الحيوية. أظهرت النتائج أن الجزيئات النانوية العصوية للذهب Rod-AuNPs هي الأفضل لنتبيط نمو البكنيرات المختبرة، تليها الجزيئات النانوية الكروية للذهب الأبط AuNPs التأثير التثبطي لجزيئات الذهب النانوية AuNPs تجاه العزلات المختبرة، ثم إعادة تلقيحها على وسط الآجار المغذي 